\title{
CHARACTERIZATION OF THE CARBOHYDRATE DEGRADING ENZYMES IN THE SURF CLAM CRYSTALLINE STYLE
}

\author{
L. F. JACOBER, C. RICE, and A. G. RAND JR.
}

\section{ABSTRACT}

The digestive enzymes within the crystalline style of the surf clam, Spisula solidissima, were examined for possible future use in algal carbohydrate degradation. Measurement and characterization of enzy matic activities, contained in a simple homogenate and useful in polysaccharide breakdown has been accomplished. The activities of amylase, cellulase, and the major enzyme, laminarinase, were evaluated by determining the amount of glucose which was released from the appropriate substrates. The activity of a fourth enzyme, alginase, was detected by a modified thiobarbituric acid test which measured the mannuronic and guluronic acids produced from an algin substrate. Conditions for the best combination of coordinated enzymatic activity were evaluated, and the majority of the crystalline style enzymes could function to a satisfactory level at $37^{\circ} \mathrm{C}$ when the $\mathrm{pH}$ was maintained at 6.0 .

\section{INTRODUCTION}

THE CRYSTALLINE style of the surf clam is part of the belly region, a troublesome waste product of the clamming industry. The style is a structure which contains an assemblage of carbohydrate digestive enzymes attached to a glycoprotein structure in one compact "package" (Shallenberger et al., 1974; Lindley and Shallenberger, 1977). The style functions by rotating against the gastric shield to grind diatomaceous and algal food while initiating enzyme hydrolysis of carbohydrate polymers (Shallenberger and Herbert, 1974; Lindley and Shallenberger, 1976). Recovery and utilization of the crystalline style may be considered as a possible source of increased revenue to the clam industry while reducing pollution and wastage.

In a study of marine invertebrates, Sova et al. (1969) examined the distribution of crystalline style laminarinase (EC 3.2.1.6) a $(\beta-1-3)$-D-glucan hydrolase effective in hydrolyzing laminarin; a reserve carbohydrate found in the brown algae, Phaeophyceae (Craigie, 1974; Percival and McDowell, 1967; Volesky et al. 1970). They concluded that the crystalline styles of Bivalvia, such as Spisula sachalinensis and Mactra sulcataria, contained the highest enzymatic activity.

Sova et al. (1970) have isolated and separated five different carbohydrases from the crystalline style of Spisula sachalinensis: laminarinase, amylase, cellulase, alginase, and chitinase. While defining optimum conditions of activity for the purified laminarinase, Sova et al. (1970) did not report the degree to which the other carbohydrase activities were present.

Shallenberger et al. (1974) have reported on three enzymatic activities in the style of the surf calm Spisula solidissima; laminarinase, amylase, and cellulase. Laminarinase was found to be the major style carbohydrase. The relative

Authors Jacober and Rand are with the Dept. of Food Science \& Technology, Nutrition \& Dietetics, Univ. of Rhode Island, Kingston, RI 02881. Author Rice, formerly of the University of Rhode Is/and, is now afriliated with the Great Lakes Research Div., Univ. of Michigan, Ann Arbor, MI 48109.

0022-1147/80/0002-0381\$02.25/0

(1980 Institute of Food Technologists activities of amylase and cellulase were compared to laminarinase and reported in terms of relative turnover of substrate. Lindley and Shallenberger (1976) further characterized laminarinase after extensive purification and separation from the other crystalline style enzymes by column chromatography. The possible utilization of the style carbohydrases, in the form of an acetone powder, to hydrolyze malt glucans was explored by Lindley and Shallenberger (1977). Effects of adsorbing laminarinase to an inert column support as a method of immobilization has also been studied (Lindley et al., 1976).

It was the intent of this study to characterize the different enzyme activities from the crystalline style of the surf clam Spisula solidissima, the principal species harvested commercially (Bakal et al., 1978). It was hoped that characterization studies of the soluble enzymes would determine the best coordination of activity so the majority of the enzymes could be utilized to function together for potential applications in algal processing.

\section{METHODS \& MATERIALS}

\section{Materials}

The crystalline styles of the surf clam Spisula solidissima were obtained from Harbourside Aqua Foods Ltd. in Exeter, R.I. The following substrates were used to characterize the different enzymatic activities: Laminarin, Sigma Chemical Co.; Wheat and Potato Starch, U.S. Biochemical Corp.; Soluble starch, Allied Chemical; and Keltone Alginate, Kelco Co. Glucose was detected with the Glucostat Kit purchased from Worthington Biochemical Corp. Uniplate ${ }^{\circledR}$ Silica Gel G thin-layer chromatography plates were obtained from Analtech, Inc. Silica Gel on plastic thin-layer chromatography plates was obtained from Brinkman Instruments. All chemicals were reagent grade. Distilled water was used throughout.

\section{Methods}

Preparation of soluble enzymes. The crystalline styles were individually frozen in polypropylene tubes and stored at $-20^{\circ} \mathrm{C}$ until needed. A $0.6 \mathrm{~g}$ wet weight sample of crystalline styles was homogenized in $10 \mathrm{ml}$ of $0.1 \mathrm{M} \mathrm{pH} 5.0$ ace tate buffer and stored at $4^{\circ} \mathrm{C}$. Prior to use, a portion of the enzyme stock was removed and a $1: 1$ dilution with buffer was made to give a final style concentration of $30 \mathrm{mg} / \mathrm{ml}$.

Laminarinase assay. This procedure was a modification of the laminarinase assay developed by Lindley and Shallenberger (1976). A $0.1 \cdot \mathrm{ml}$ aliquot of the $30 \mathrm{mg} / \mathrm{ml}$ crystalline style homogenate was added to a $12-\mathrm{ml}$ centrifuge tube containing $0.3 \mathrm{ml}$ of $0.4 \%(\mathrm{w} / \mathrm{v})$ laminarin solution in $0.1 \mathrm{M}$ acetate buffer at $\mathrm{pH} 5.0$ and $0.1 \mathrm{ml}$ of distilled water to give a final substrate concentration of $0.24 \%$. The reaction mixture was agitated at $175 \mathrm{rpm}$ at $37^{\circ} \mathrm{C}$ in a shaker water bath. The reaction was stopped after $20 \mathrm{~min}$ by deproteinizing with $1.0 \mathrm{ml}$ of $1.8 \% \mathrm{Ba}(\mathrm{OH})_{2} \cdot 8 \mathrm{H}_{2} \mathrm{O}$ followed by $1.5 \mathrm{ml}$ of distilled water and finally $1.0 \mathrm{ml}$ of $2.0 \% \mathrm{ZnSO}_{4} \cdot 7 \mathrm{H}_{2} \mathrm{O}$. The tubes were mixed thoroughly and centrifuged for $5 \mathrm{~min}$ at approximately 2000 $\times$ G. Glucose produced was estimated colorimetrically with a modified Glucostat procedure (Hourigan, 1976). The chromogen vial, regularly associated with the Glucostat kit, was first diluted with 5.0 $\mathrm{ml}$ of distilled water. The chromogen and enzyme vials were then brought to a $100 \mathrm{ml}$ volume with $\mathrm{pH} 7.00 .1 \mathrm{M}$ sodium phosphate buffer. A $0.5-\mathrm{ml}$ aliquot of supernatant was then reacted with 2.0 $\mathrm{ml}$ of Glucostat reagent at $37^{\circ} \mathrm{C}$ for exactly $10 \mathrm{~min}$. The reaction was terminated by the addition of $0.2 \mathrm{ml}$ of $5 \mathrm{~N}$ hydrochloric acid. The absorbance was then read at $425 \mathrm{~nm}$ on a Baush and Lomb Spectronic 20 colorimeter equipped with a flowthrough cell. Glucose levels were determined by reference to a standard curve of known glucose concentrations ranging from $0-100 \mu \mathrm{g} / \mathrm{ml}$. The 


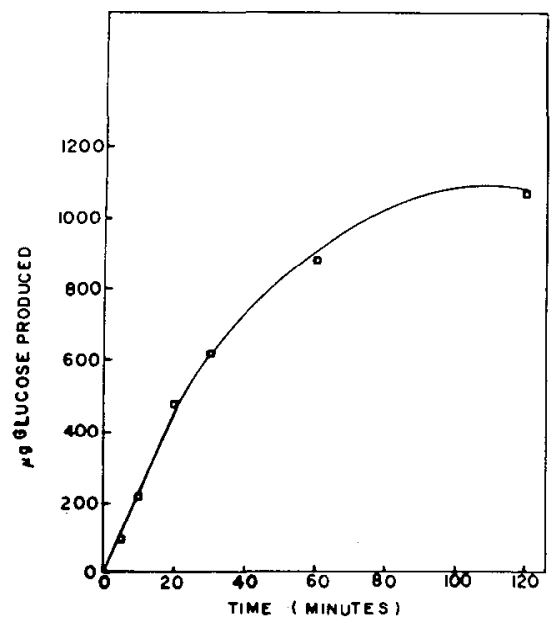

Fig. 1-Glucose produced by laminarinase at $37^{\circ} \mathrm{C}$ and $\rho \mathrm{H} 5.0$ with a substrate concentration of $0.24 \%$ lenzyme conc used in assay0.65 units).

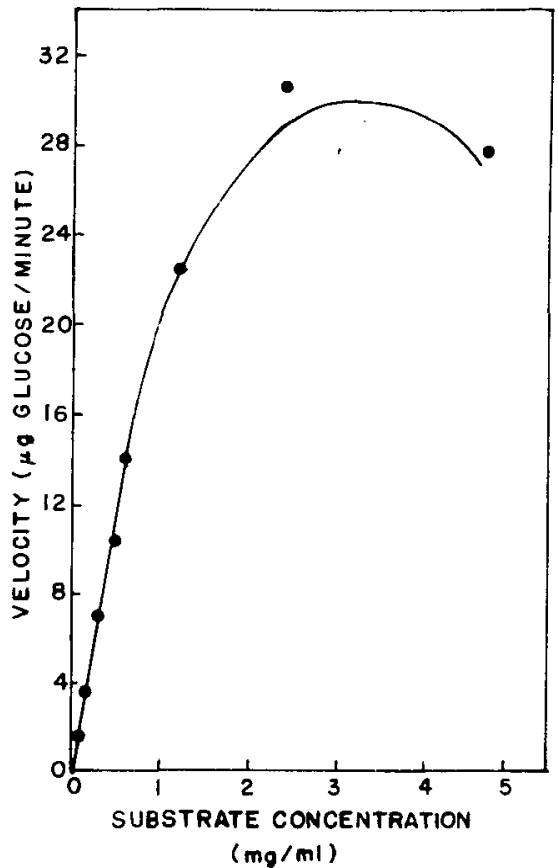

Fig. 2-Effect of substrate concentration on laminarinase activity at $37^{\circ} \mathrm{C}$ and $\mathrm{pH} 5.0$ after $10 \mathrm{~min}$ renzyme conc used in assay0.83 units).

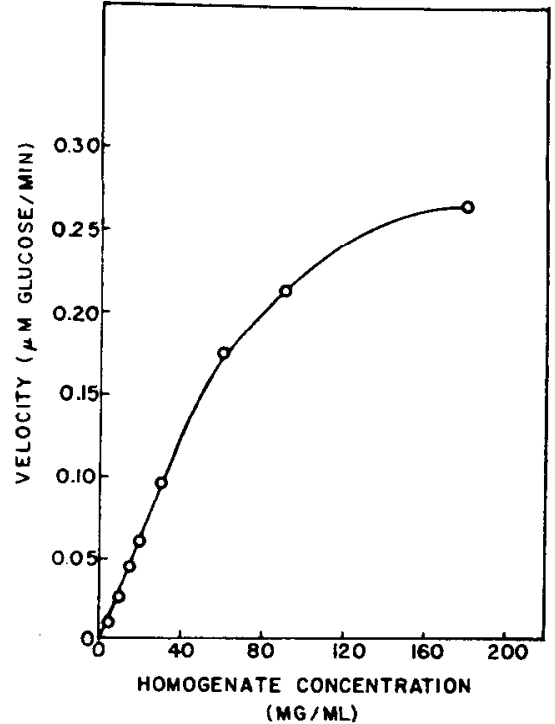

Fig. 3-Effect of concentrations of crystalline style homogenate, evaluated as laminarinase, on velocity at $37^{\circ} \mathrm{C}$ and $\mathrm{pH} 5.0$ with a substrate concentration of $0.24 \%$ after 20 min lenzyme canc used in assay -0.48 units). amount of glucose generated through enzymatic action was determined by subtracting the level of glucose initially present in a blank of substrate and enzyme homogenate from the glucose measured at the end of the reaction.

The assay conditions were also studied at various temperature, substrate, and enzyme concentrations. The effects of temperature were studied at $37^{\circ} \mathrm{C}, 45^{\circ} \mathrm{C}$, and $50^{\circ} \mathrm{C}$ for 5 and $10 \mathrm{~min}$. Laminarin concentrations ranging from $0.0125 \%-0.80 \%(w / v)$ were run for $10 \mathrm{~min}$ at $37^{\circ} \mathrm{C}$. Enzyme homogenate concentrations were varied, ranging from $5 \mathrm{mg} / \mathrm{ml}-180 \mathrm{mg} / \mathrm{ml}$, and run for $20 \mathrm{~min}$.

Amylase assay. Solutions of Argo corn starch, wheat starch, potato starch, tapioca starch, and soluble starch at $1.0 \%(\mathrm{w} / \mathrm{v})$ were prepared in $0.1 \mathrm{M} \mathrm{pH} 5.0$ acetate buffer. The $30 \mathrm{mg} / \mathrm{ml}$ enzyme homogenate, $0.1 \mathrm{ml}$, was added to a $12-\mathrm{ml}$ centrifuge tube contain ing $0.3 \mathrm{ml}$ of a $1.0 \%$ starch solution and $0.1 \mathrm{ml}$ of $0.2 \mathrm{M} \mathrm{NaCl}$. The reaction mixture was agitated at $175 \mathrm{rpm}$ at $37^{\circ} \mathrm{C}$ in a shaker water bath. Deproteinization and centrifugation followed, as outlined above, and the degree of amylase activity was evaluated by determining the amount of glucose released with the modified Glucostat procedure, already described.

Cellulase Assay. The substrate, Whatman \#1 filter paper, was dispersed in $0.1 \mathrm{M} \mathrm{pH} 5.0$ acetate buffer with a microblender and a final suspension of $4.3 \mathrm{mg} / \mathrm{ml}$ was obtained. The $30 \mathrm{mg} / \mathrm{ml}$ enzyme homogenate, $0.1 \mathrm{ml}$, was added to $0.3 \mathrm{ml}$ of cellulose substrate and $0.1 \mathrm{ml}$ of distilled water and agitated at $37^{\circ} \mathrm{C}$. Employing the analytical procedures outlined in the laminarinase assay, deproteinization and centrifugation followed and cellulase activity was evaluated by measuring the amount of glucose released with the modified Glucostat procedure.

Alginase determination. Keltone algin at $0.4 \%(w / v)$ was dispersed in $0.1 \mathrm{M}$ acetate buffer as outlined by Kelco (1976). The method of preparation was high sheer mixing. A stirrer was used and the powdered algin was added slowly onto the upper portion of the vortex. A $1.0-\mathrm{ml}$ aliquot of the $30 \mathrm{mg} / \mathrm{ml}$ enzyme homogenate was added to $3.0 \mathrm{ml}$ of the $0.4 \%$ algin solution and $1.0 \mathrm{ml}$ of distilled water and agitated at $37^{\circ} \mathrm{C}$ in a shaker water bath. Samples $(0.2 \mathrm{ml})$ of the reaction mixture were removed at the desired time intervals and alginase activity was evaluated colorimetrically with a thiobarbituric acid method first developed by Waravdekar and Saslaw (1957) and further modifed by Weissbach and Hurwitz (1958). The procedure of Weissbach and Hurwitz (1958) was followed closely with a few modifications. A $0.25-\mathrm{ml}$ portion of $0.025 \mathrm{~N} \mathrm{KIO}_{4}$ in $0.125 \mathrm{~N}$ $\mathrm{H}_{2} \mathrm{SO}_{4}$ was added to $0.2 \mathrm{ml}$ of the reacted mixture and allowed to stand at room temperature for exactly $20 \mathrm{~min}$. Then $0.5 \mathrm{ml}$ of $2.0 \%$ $\mathrm{NaAsO}_{2}$ in $0.5 \mathrm{~N} \mathrm{HCL}$ was added, and the contents mixed vigorously, and permitted to stand for $2 \mathrm{~min}$. This was followed by 2.0 $\mathrm{ml}$ of $0.3 \%$ 2-thiobarbituric acid ( $\mathrm{pH} 2.3)$ which reacted with the aldehyde derivatives of guluronic acid and mannuronic acids by heating at $100^{\circ} \mathrm{C}$ for $10 \mathrm{~min}$. The assay solution was cooled quickly in an ice bath, brought to room temperature, and the absorbance was read at $550 \mathrm{~nm}$ in a Baush and Lomb Spectronic 20. Initial levels were determined with an enzyme-substrate blank. Degree of algin degradation was determined from a standard curve of known 1,1,3,3-tetraethoxypropane concentrations ranging from $0-25$ $\mathrm{\mu g} / \mathrm{ml}$, which hydrolyzes under acid conditions to form malonaldehyde.

Thin Layer Chromatography Method. The basic thin-layer chromatography procedure followed was of Lee and Lillibridge (1976) with several modifications. At least $24 \mathrm{hr}$ prior to use, a standard sealed glass chromatography chamber, lined with filter paper, was allowed to saturate with n-butanol/acetic acid/0.3M boric acid solvent. Silica gel plates on plastic or glass supports were activated for $1 \mathrm{hr}$ at $100^{\circ} \mathrm{C}$ (Hart and Fisher, 1971) and stored in a desiccator until needed. Standards, at a concentration of $0.5 \%$ $(w / v)$, and reacted mixtures, without deproteinization, were added to the TLC plates with disposable capillary tubes. Approximately 10 drops of reacted mix ture were applied to insure adequate detection. Every application was dried with hot air to visual dryness. After the solvent front was allowed to migrate $10-15 \mathrm{~cm}$ from the top of the plate, the plate was removed and allowed to air dry for approximately $10 \mathrm{~min}$ to remove excess solvent. It was the placed in a $55-60^{\circ} \mathrm{C}$ oven for $1 \mathrm{hr}$. The color developer of $0.5 \% \mathrm{KMnO}$, in 1.0N NaOH (Hart and Fischer, 1971; Randerath, 1966) was then sprayed on the plate with a glass atomizer and heated in a $55-60^{\circ} \mathrm{C}$ oven to facilitate drying and until distinct yellow spots on a purple background were observed.

pH Studies. Effect of $\mathrm{pH} 5.0,5.5$, and 6.0 on laminarinase, amylase, and alginase activities was studied. The enzyme homogenate was made in $0.1 \mathrm{M}$ ace tate buffer at either $\mathrm{pH} 5.0$ or 5.5 . The substrates were dispersed in $0.1 \mathrm{M}$ acetate buffer at $\mathrm{pH} 5.0,5.5$, or 6.0. Assays were carried out as previously described and reaction products were evaluated with the analytical and/or TLC methods. Those studies run at $\mathrm{pH} 6.0$ utilized the enzyme homogenate stored in $\mathrm{pH} 5.5$ buffer for stability. 
Definition of activity. Expression of glucose production due to amylase, cellulase and laminarinase activity for the tables and graphs is based on $1.0 \mathrm{ml}$ of assay mix ture unless otherwise stated.

A unit of laminarinase activity was defined as that amount of enzyme needed to produce $0.1 \mathrm{micromole}$ glucose/minute under the assay conditions described. All enzyme units are expressed as the amount per $1.0 \mathrm{ml}$ of enzyme homogenate containing $30 \mathrm{mg} / \mathrm{ml}$ unless otherwise noted.

\section{RESULTS \& DISCUSSION}

THE EXTENT to which product formation was proportional to time under the conditions set for the laminarinase assay is presented in Figure 1. Linearity was maintained for $20 \mathrm{~min}$. Initial velocity values or activity units for laminarinase were calculated from assays run for not less then 10 and not more than $20 \mathrm{~min}$ which maximized reproducibility. Enzyme activity over this time period resulted in laminarin hydrolysis of $9-20 \%$. Enzymatic hydrolysis of laminarin appeared to plateau at $45 \%$ by $2 \mathrm{hr}$. Based on an average weight of $0.6 \mathrm{~g}, 10 \mathrm{ml}$ of style homogenate with a concentration of $30 \mathrm{mg} / \mathrm{ml}$ contained approximately $6-7$ units and one style contains $120-140$ units of laminarinase activity.

The conditions of laminarinase assay were further evaluated by varying substrate concentrations. In the data illustrated by Figure 2, it was cvident that substrate inhibition was a problem. The best rate of approximately $30 \mu \mathrm{g} / \mathrm{ml}$ of reaction mixture $/ \mathrm{min}$ was obtained at a final assay concentration of $0.24 \%$ or $2.4 \mathrm{mg} / \mathrm{ml}$ laminarin. The activity of laminarinase was subject to normal biological variability between clams. Therefore, any increase in substrate concentration much beyond $0.24 \%$, though possibly increasing maximum velocity slightly, could manifest itself as substrate inhibition to an enzyme which was not quite as active.

Figure 3 illustrates the effect of varying enzyme concentrations while using $0.24 \%$ laminarin and allowing the reaction to proceed for the maximum duration of linearity, 20 $\min$. The homogenate, containing $30 \mathrm{mg} / \mathrm{ml}$, used in the assay procedure, appeared to be appropriate for the conditions set. Though a slightly higher concentration of enzyme might result in increased activity while remaining linear for $20 \mathrm{~min}$, an increase in enzyme concentration may result in a condition where linearity could end prior to $20 \mathrm{~min}$ and consequently erroneous data would be obtained.

The variation of laminarinase activity with temperature is shown in Figure 4. Maximum activity, after a 10-min incubation time occurred at $50^{\circ} \mathrm{C}$. As noted by Lindley and Shallenberger (1976) for the purified enzyme, the high temperature optimum is surprising for a marine organism. Though not illustrated, the temperature optimum was $55^{\circ} \mathrm{C}$ for a 5-min assay. This would seem to indicate that with extended incubation of the enzyme, the operational temperature would be lower than the optimum due to instability.

Laminarin is essentially a linear $\beta(1-3)$-linked glucan and predominantly yields glucose upon hydrolysis with laminarinase. However, mannitol is also an important structural constituent of laminarin. Laminarin has been found to contain both glucose and mannitol terminated molecules (Craigie, 1974; Percival and McDowell, 1967). Mannitol ranges from $2.4-37 \%$ of both soluble and insoluble laminarin depending on the source (Craigie, 1974). Therefore, the laminarinase assay was followed for $90 \mathrm{~min}$ with thin-layer chromatography to qualitatively determine any possible formation of other products from laminarin as a result of enzymatic hydrolysis. These would include the disaccharide laminaribiose, which was found to accumulate with lengthy hydrolysis (Sova et al., 1970), and any higher oligosaccharides which might be formed by the hydrolytic reaction.

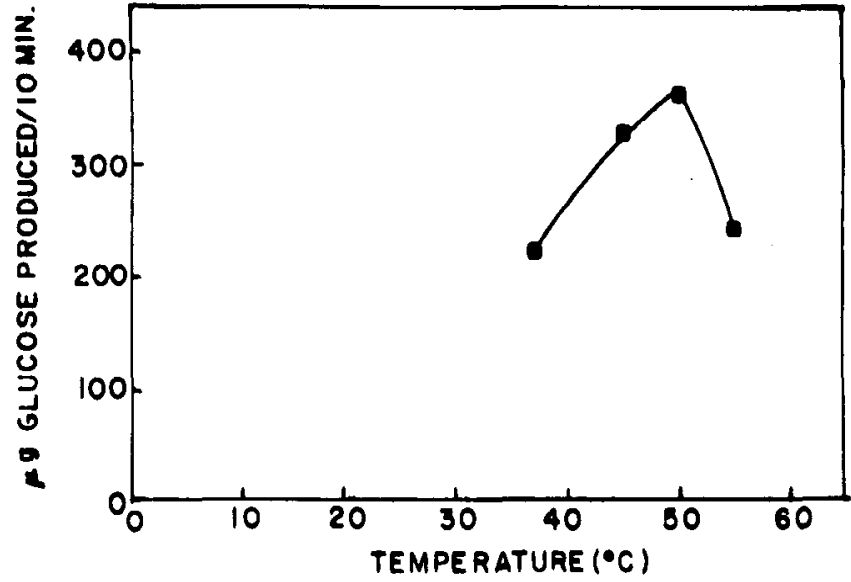

Fig. 4 -Effect of temperature on laminarinase activity at $\mathrm{pH} 5.0$ and a substrate concentration of $0.24 \%$ after $10 \mathrm{~min}$ (enzyme conc used in assay -0.62 units).

Glucose, mannitol, laminarin, maltose, and all possible combinations were used as standards. Maltose, the $\alpha(1-4)$-glucan, was used as a comparison for laminaribiose. Samples of the reacted laminarinase assay were taken from 5-90 min and applied to the TLC plates.

The TLC results are illustrated by Figure 5. Based on the $R_{f}$ values and standard comparison, it was determined that compound \#1 was glucose. As interpreted from the color intensity, glucose increased dramatically with time until difference in color could no longer be detected visually. Compound \#6, laminarin, and compounds 4 and 5, probably oligosaccharides resulting from partial hydrolysis, decreased with time. Since compound \#3 migrated farther, it

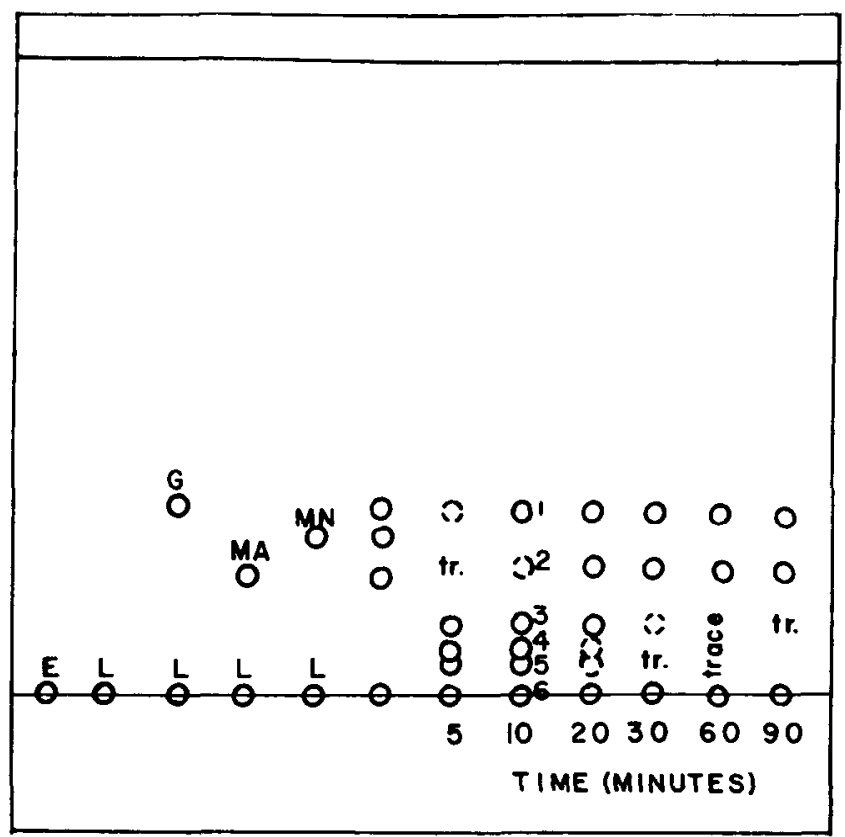

Esenzyme homogenate; $L=$ laminarin; $G=$ glucose

$M A=\operatorname{moltose} ; M N=$ mannitol

Fig. 5-Thin-layer chromatographic representation of laminarinase hydrolysis from 5-90 min at conditions of $37^{\circ} \mathrm{C}$ and $\mathrm{pH} 5.0$. 
was considered a smaller oligosaccharide, which increased during the first $10 \mathrm{~min}$ and then began to decrease.

The most interesting result of this procedure was the presence of compound \#2. This product seemed to form almost immediately and steadily increased. Based on its mobility, an $R_{f}$ value only slightly greater than maltose, in comparison to the standards and other polymers, this compound was probably a disaccharide. Since there was no standard which could be used to positively identify this unknown, there seemed to be two possibilities: laminaribiose, or a glucose-mannitol. Whichever the compound was, it is important to note that its formation coincides with glucose production. Both end-products were the result of enzymatic action on laminarin.

Figure 6 presents the results obtained from crystalline style homogenate activity, on various starches, in terms of glucose production. The crystalline style amylase exhibits varied activity on different starches. Whistler and Paschall (1965) described such varied activity as being typical of this enzyme system. The enzyme exhibited maximum activity on wheat starch after $2 \mathrm{hr}$, though the overall glucose production was similar with tapioca. The degradation of potato and soluble potato starches to glucose had the slowest rates and did not reach the same levels as wheat, tapioca, or corn. These results confirmed the findings of Shallenberger et al. (1974) as to the presence of amylase activity in the surf clam Spisula solidissima.

Since the amylases were quantitatively measured in terms of only glucose production, the total hydrolyzing capabilities of the amylase system were also evaluated with TLC. Thin-layer chromatography was used to examine the products of the reaction and establish the effect of $\mathrm{pH}$ on the amylase activity of the homogenate on starch. Tapioca was used as the substrate. As estimated by the color intensity of the spots of reacted mixtures, glucose, maltose and

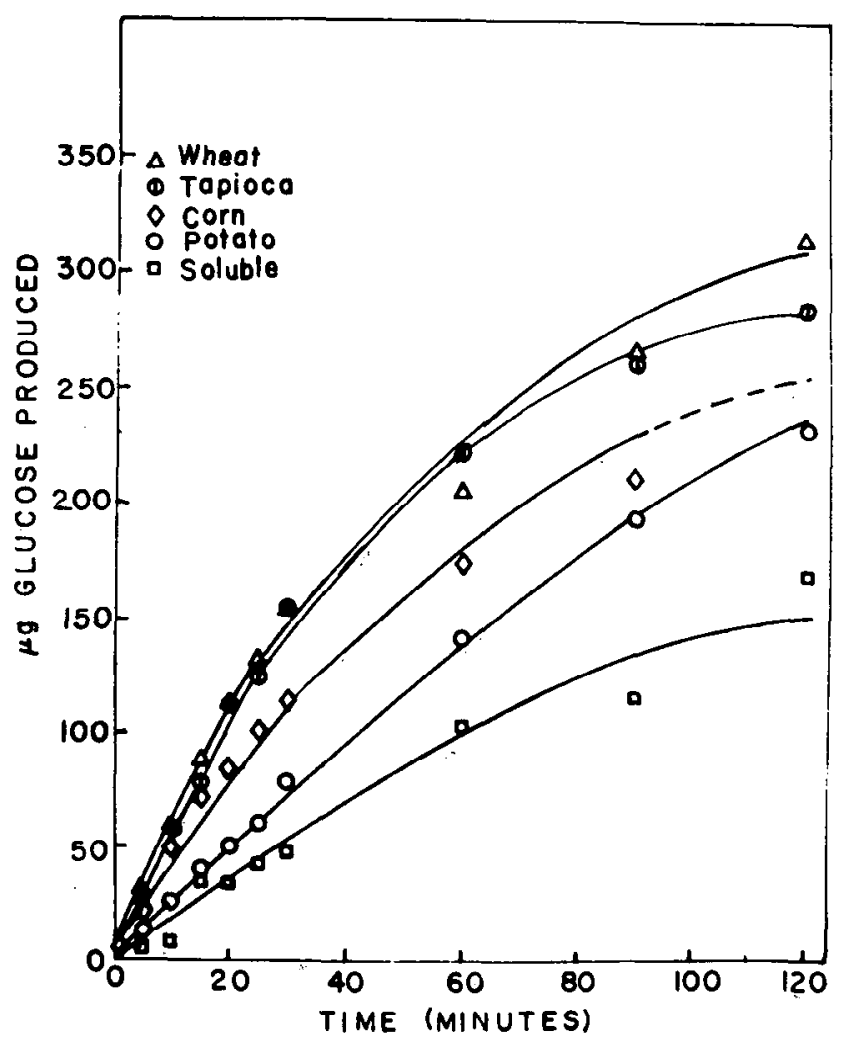

Fig. 6-Glucose hydrolyzing capabilities of the crystalline style homogenate, as amylase, on different starches at $37^{\circ} \mathrm{C}$ and $\mathrm{pH}$ 5.0. other small oligosaccharides increased as the $\mathrm{pH}$ of the reaction was increased from $\mathrm{pH} 5.0$ to $\mathrm{pH}$ 6.0. Measurement of the individual amylases was not accomplished.

Following the conditions outlined by the amylase assay, indications of maltase activity were observed when a preliminary study was run using maltose as the substrate. Glucose values slowly increased in a linear manner after the enzyme homogenate was added to the reaction mixture. These results agree with Shallenberger et al. (1974), who also found a small degree of maltase activity only in the presence of $\mathrm{NaCl}$. The existence of maltase would infer that the total glucose measured in the amylase experiments was probably due to the combined action of the amylase and maltase enzy mes.

Cellulase activity was also evaluated and the results are illustrated by Table 1 . Increasing the enzyme concentration five times increased the glucose production by a factor of seven after $2 \mathrm{hr}$. Under the conditions of this assay, cellulase activity within the crystalline style was limited.

Finally, alginase activity was discovered in this specie of Spisula. Figure 7 illustrates the effect of $\mathrm{pH}$ on alginase activity. An increase in $\mathrm{pH}$ from $\mathrm{pH} 5.0$ to $\mathrm{pH} 6.0$ resulted in an activity increase of nine times after $25 \mathrm{hr}$. The reaction at $\mathrm{pH} 6.0$ exhibited proportional algin hydrolysis over the entire reaction period when compared to $\mathrm{pH} 5.0$ and pH 5.5. Preliminary analysis wih $0.2 \mathrm{M} \mathrm{NaCl}$ indicated a slight stimulation of alginase activity. Though alginase activity. was present, it was not found in appreciable quantities when tested under the experimental conditions.

Since an increase to $\mathrm{pH} 6.0$ would enhance the activities

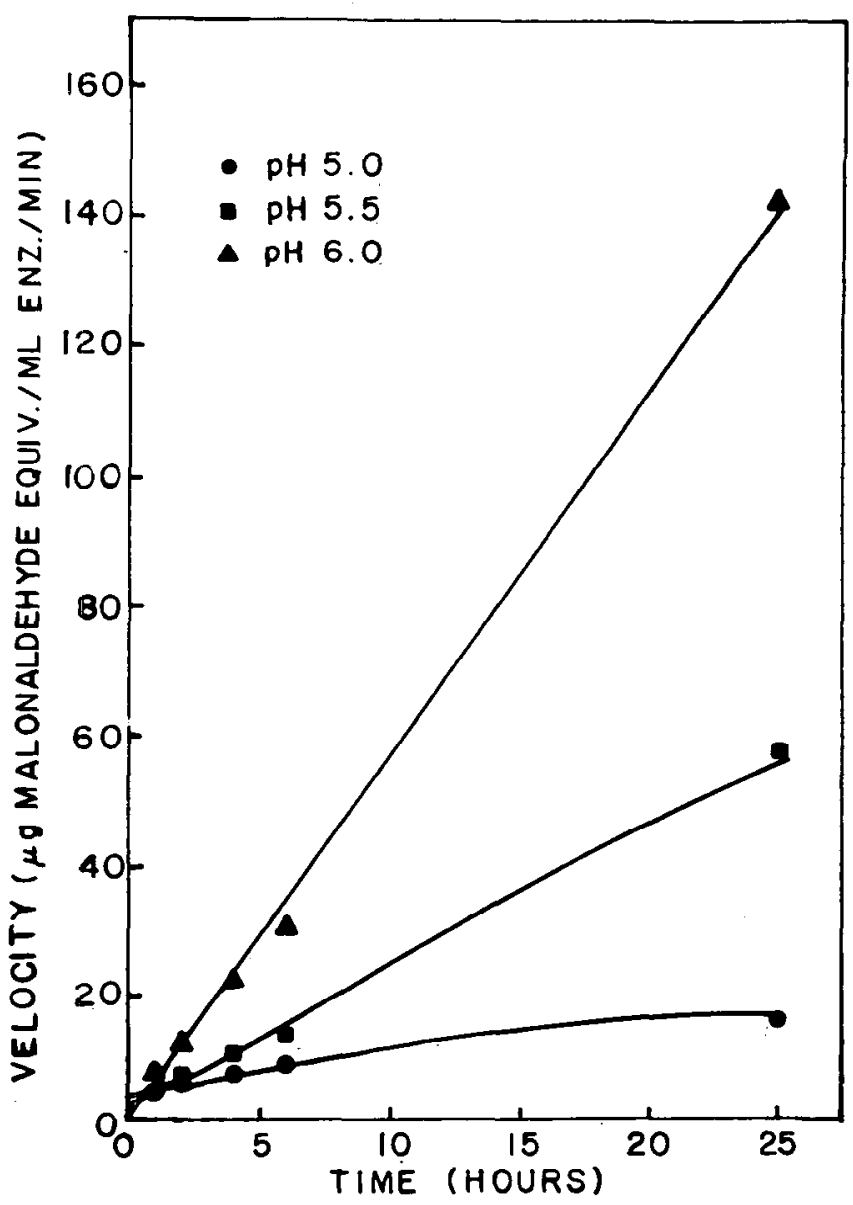

Fig. 7-Effect of $\mathrm{pH}$ on alginase activity at $37^{\circ} \mathrm{C}$ and algin concentration $0.24 \%$. 
Table 1-Comparison of relative activity at 1 and 2 hr at $p H 5.0$ and $37^{\circ} \mathrm{C}$ of cellulase to laminarinase

\begin{tabular}{|c|c|c|c|c|c|}
\hline Enzyme & Substrate & $\begin{array}{c}\text { Enzyme conc } \\
(\mathrm{mg} / \mathrm{ml})\end{array}$ & $\begin{array}{c}\text { Time } \\
\text { (hr) }\end{array}$ & Activity ${ }^{a}$ & $\begin{array}{c}\text { Relative } \\
\text { turnover }\end{array}$ \\
\hline Laminarinase & $\begin{array}{l}0.4 \% \\
\text { Laminarin }\end{array}$ & 30 & $\begin{array}{l}1 \\
2\end{array}$ & $\begin{array}{l}4418.0^{\mathbf{c}} \\
5359.5\end{array}$ & $\begin{array}{l}100 \\
100\end{array}$ \\
\hline \multirow[t]{2}{*}{ Cellulase } & $\begin{array}{l}0.4 \% \mathrm{~d} \\
\text { Cellulose }\end{array}$ & 30 & $\begin{array}{l}1 \\
2\end{array}$ & $\begin{array}{r}7.7 \\
15.4\end{array}$ & $\begin{array}{l}0.17 \\
0.29\end{array}$ \\
\hline & & 150 & $\begin{array}{l}1 \\
2\end{array}$ & $\begin{array}{r}74.0 \\
105.2\end{array}$ & $\begin{array}{l}1.7 \\
2.0\end{array}$ \\
\hline
\end{tabular}

a $\mu \mathrm{g}$ glucose $/ \mathrm{ml}$ enzyme homogenate

b Glucose produced by cellulase relative to glucose produced by laminarinase

c Enzyme concentration used in assay- 0.65 units

d Approximate concentration

Table 2-Effect of $p H$ on laminarinase at 30 and $60 \mathrm{~min}$ at $37^{\circ} \mathrm{C}$

\begin{tabular}{ccc}
\hline Time $(\min )$ & \multicolumn{2}{c}{ Glucose produced } \\
\hline & $\mathrm{pH} 5.0^{\mathrm{a}}$ & $\mathrm{pH} 6.0$ \\
30 & 632 & 516 \\
60 & 868 & 728 \\
\hline
\end{tabular}

a Enzyme concentrations used in assay -0.63 units

of amylase and alginase, the effect of $\mathrm{pH}$ on laminarinase was studied. As illustrated by Table 2, there was an approximately $15 \%$ decrease in activity if $\mathrm{pH} 6.0$ were used.

The alginase and cellulase were considered marginal enzymes in the crystalline style. The overriding enzyme systems were laminarinase and amylase. The $\mathrm{pH}$ did not seem to have a serious affect on laminarinase activity, and the TLC results indicated the stimulation of amylase activity when the $\mathrm{pH}$ was increased above $\mathrm{pH} 5.0$. Therefore, the conditions for operation of the combined style enzyme system activity appears to be $\mathrm{pH} 6.0$ when the temperature is held at $37^{\circ} \mathrm{C}$.

\section{REFERENCES}

Bakal, A., Rathjen, W.F., and Mendelson, J. 1978. Ocean quahog takes supply spotlight as surf clam dwindles. Fd. Prod. Dev. 12(1): 71 .
Craigie, J.S. 1974. Storage products. In "Algal Physiology and Biochemistry," Ed. W.D.P. Stewart, p. 206.

Hart, F.L. and Fisher, H.J. 1971. "Modern Food Analysis," Springer-Verlag, New York.

Hourigan, J.A. 1976. "Kinetic Studies of Enzyme Hydrolysis of Lactose. Ph.D. dissertation, U.R.I. Manuscript 1: p. 7.

Kelco. 1976. "Kelco Algin/Hydrophilic Derivatives of Alginic Acid for Scientific Water Control." Kelco, Div. of Merck and Co., Inc., Sales Office, Clark, N.J.

Lee, D. E and Lillibridge, C.B. 1976. A method for qualitative identification of sugars and semiquantitative determination of lactose content suitable for a variety of foods. Am. J. Clinical Nutrit. 29: 428 .

Lindley, M.G. and Shallenberger, R.S. 1976. Purification and characterization of a mollusc. $\beta-D-(1-3)$-Glucan hydrolase. Fd. Chem. 1: 149 .

Lindley, M.G., Braverman, S.E., and Shallenberger, R.S. 1976. The catalytic properties of laminarinase strongly absorbed. Personal communication.

Lindley, M.G. and Shallenberger, R.S. 1977. Enzyme hydrolysis of malt glucans using a molluse carbohydrase preparation. Fd. Chem. 2: 1

Percival, F. and MeDowell, R.H. 1967. "Chemistry and Enzymology of Marine Algal Poly saccharides." Academic Press, New York.

Randerath, K. 1966. "Thin Layer Chromatography." Verlag Chemie, Academic Press, New York.

Shallenberger, R.S. and Herbert, S.M. 1974. Nature's Immobilized Enzy me. New York's Fd and Life Sci.

Shallenberger, R.S., Searles, C., and Lewis, B.A. 1974. Laminarinase activity in the crystalline style of the surf clam (Spissula solidissima). Experimenta 30: 597.

Sova, V.V., Elyakova, L.A., and Vaskivsky, V.E. 1969. The distribution of laminaranase in marine invertebrates. Comp. Biochem. Physiol. 32: 459 .

Sova, V.V., Ely akova, L.A., and Vaskovsky, V.E. 1970. Purification and some properties of $\beta-1-3$-glucanohydrolase from crystalline style of bivalva, Spissula sachalinensis. Biochem. Biophys, Acta. 212: 111 .

Volesky, B., Zajic, J.E., and Knettig, E. 1970. Algal properties. Properties and products of algae. "Symposium on the Culture of Algae by the Division of Microbial Chemistry and Technology of the American Chemical Society," Ed. J.E. Zajic. Plenum Press.

Waravdekar, V.S. and Saslaw, L.D. 1957. A method of estimation of 2-deoxyribose. Biochim. Biophys. Acta. 24: 439.

Weissbach, A. and Hurwitz, J. 1959. The formation of 2-ketodeoxyheptonic acid extracts of Escherichia coli B. J. Biol. Chem. 234: 705 .

Whistler, R. and Paschall, E. 1965. "Starch Chemistry and Technology," Part 1. Academic Press, New York.

Ms received 7/4/79; revised 9/21/79; accepted $9 / 28 / 79$

Contribution No. 1865 of the RI Agricultural Experiment Station.

This work was part of the thesis fulfillment for a master's degree at the University of Rhode Island, Kingston, R.I. Part of this material was presented at the 21st Annual Meeting of the Atlantic Fisheries Technological Conference, Newport, R.I., Oct. 17-20, 1976. This study was supported by the Rhode Island Agricultural Experiment Station and the Cooperative State Research Service, U.S. Department of Agriculture.

INFLUENCE OF SORBIC ACID ON A. parasiticus ... From page 376

acid of the germination of spores of Aspergillus niger. Nature 179: 922 .

Harada, K.. Higuchi, R., and Utsumi, I. 1968. Studies on sorbic acid. Part 4. Inhibition of the respiration in yeast. Agr. Biol. Chem 32: 940 .

Harold, F.M., Baarda, J.R., and Pavlasova, E. 1970. Extrusion of sodium and hydrogen ions as the primary process in potassium ion accumulation by Streptococcus faecalis. J. Bacteriol. 101: 152 .

Hunter, D.R. and Segel, I.H. 1973. Effect of weak acids on amino acid transport by Penicillium chrysogenum: Evidence for a proton or charge gradient as the driving force. I. Bacteriol. 113: 1184.

Mitchell, P. 1961. Coupling of phosphorylation and hydrogen transfer by a chemiosmotic mechanism. Nature 191: 144 .

Pressman, B.C. and Lardy. HA. 1966. Effect of surface active agents on the latent ATPase of mitochondria. Biochim. Biophys Acta. 21: 458 .

Sofos, J.N., Busta, F.F. Bhothipaksa, K., and Allen, C.E. 1979 Sodium nitrite and sorbic acid effects on Clostridium botulinum toxin formation in chicken frankfurter-type emulsions. J. Food Sci. 44: 668 .

St. John, J.B. 1970. Determination of ATP in Chorella with the luciferin tuci ferase enzyme system. Anal. Biochem. 37: 409.

Strehler, B.L. 1965. Adenosine-5'-triphosphate and creatine phosphate. In "Methods of Enzymatic Analysis," Ed. Bergmeyer, H.V., p. 2112. Academic Press, New York.

Troller, $\mathrm{J}_{1} \mathrm{~A}$. 1965 . Catalase inhibition as a possible mechanism of the funpistatic action of sorbic acid. Can. J. Microbiol. 11: 611. Whitaker, J.R. 1959. Inhibition of sulfhydryl enzymes with sorbic acid. Food Research 24: 37.

York, G.K. and Vaughn, R.H. 1964. Mechanisms in the inhibition of microorganisms by sorbic acid. J. Bacteriol. 88: 411 . Ms received $6 / 13 / 79$; revised $9 / 21 / 79$; accepted $9 / 28 / 79$

Presented at the 39th Annual Meeting of the Institute of Food Technologists, St. Louis, Mo.. June 10-13, 1979.

Published as Paper No. 5806 , Journal Series Agricultural Experiment Station, Lincoln, NE 68583 . Research was conducted under Project 16-029. 